\title{
Strategi Komunikasi dan Dakwah Pada Kalangan Milenial di Era Modernisasi
}

\author{
Retna Dwi Estuningtyas \\ Universitas Ibnu Chaldun Jakarta \\ reretnadwie@gmail.com
}

Dakwah
Komunikasi
Milenial
Da’i

\section{Kata Kunci:}

\begin{abstract}
Abstraksi
Perkembangan dakwah di masa modern ini sangat pesat, mengalami banyak perubahan terutama dalam berstrategi. Komunikasi dan dakwah adalah dua bidang yang tidak bisa dipisabkan satu dengan lainnya. Keberhasilan gerakan dakwah sangat ditentukan oleh kompetensi seorang da'i. Membahas komunikasi dan dakwah kepada kaum milenial ini tentu sesuatu yang menarik, di mana diketabi bahawa kaum milenial adalah kaum yang senantiasa melibatkean kegiatan komunikasi dengan dunia yber atau mereka lebih familiar terhadap media social dan apapun yang berbau teknologi untuk informasi. Penggunaan metode yang tepat guna dengan memanfatkan media social tentu harus memperhatikan banyak hal, diantaranya adalab Bahasa media dan jenis media social itu sendiri. Dengan demikian dakwah di kalangan milenial ini dapat mencapai hasil yang diharapkan.
\end{abstract}

Copyright (O) 2021 (Retna Dwi Estuningtyas) DOI: https://doi.org/10.52593/mtq.02.1.05 Naskah diterima: 27 November 2020, direvisi: 14 Januari 2021, disetujui: 20 Januari 2021

\section{A. Pendahuluan}

Memasuki era modern saat ini definsi dan pemahaman masyarakat tentang dakwah mengalami kemajuan dan perkembangan yang cukup penting. Dakwah tidak hanya dipahami sebagai upaya penyampaian ajaran Islam melalui pengajian, khutbah Jumat, ceramah di atas mimbar, dan sejenisnya akan tetapi pemahaman dakwah lebih dari sekedar itu. Pemahaman dakwah bukanlah pemahaman konvensional berupa rutinitas spiritual yang kolektif, melainkan dakwah juga bisa berupa tindakan pemberian santunan kepada panti asuhan, mengentaskan kemiskinan, penanggulangan bencana dan berbagai aktivitas kemanusiaan lainnya (Ujang Mahadi, 2015: 22).

Perkembangan zaman menimbulkan dampak munculnya berbagai persoalan menjadi lebih kompleks. Sebaliknya pelaksanaan kegiatan dakwah tampak belum ada perkembangan yang berarti, semisal upaya perombakan atau redefenisi fungsi. Yang kita lihat sekarang adalah semacam penyegaran terhadap fungsi dakwah. Alasannya, karena perkembangan zaman makin melahirkan keanekaragaman sasaran dakwah. Milenial sebagai kekuatan yang seharusnya menjadi penggerak perubahan sosial secara positif, dakwah seolah tidak sanggup menghidupkan nilai-nilai agama dalam kehidupan masyarakat secara produktif.

Padahal secara sosiologis, dakwah pada dasarnya dimaksudkan untuk menghidupkan fungsi-fungsi sosial yang tumbuh dan berkembang di masyarakat. (Aida Noer Aini, Muhamad Ridwan Effendi, 2021; Effendi, 2021) Karena itu adanya pranata sosial seperti hukum, politik, ekonomi, pendidikan, budaya dan bahkan agama, idealnya dapat memberikan manfaat bagi masyarakat, bukan malah sebaliknya, melahirkan berbagai mudarat bagi kehidupan (Asep Saeful Muhtadi, 2015: 40). 
Dalam keadaan seperti itu, komunikasi dakwah terhadap kaum milenial diharapkan dapat menawarkan solusi sebagai upaya produktif dalam melakukan rekayasa individu dan masyarakat melalui proses transformasi nilai-nilai sesuai dengan pesan-pesan ajaran Islam.

Dalam mewujudkan nilai-nilai komunikasi dakwah tersebut, komunikator atau da’i harus memiliki konsep dan metode dalam mengkomunikasikan dakwah kepada masyarakat milenial. Dalam proses dakwah pastinya menggunakan metode, tetapi metode tersebut harusnya disesuaikan dengan kondisi yang dihadapi. Untuk itu dipertimbangkan metode yang akan digunakan dan cara penerapannya, karena sukses dan tidaknya suatu program dakwah sering dinilai dari segi metode yang digunakan. Hal ini disebabkan masalah yang dihadapi oleh dakwah semakin berkembang dan kompleks, sehingga metode yang berhasil di suatu tempat tidak dapat dijadikan tolak ukur untuk daerah lain.

Dakwah dakwah sebagai seruan atau ajakan kepada keinsyafan, atau usaha mengubah situasi yang tidak baik kepada situasi yang lebih baik dan sempurna baik terhadap pribadi maupun masyarakat (M. Quraish Shihab, 2012: 194).

Komunikasi sendiri adalah suatu proses di mana dua orang atau lebih membentuk atau melakukan pertukaran informasi dengan satu sama lainnya, yang pada gilirannya akan tiba pada saling pengertian yang mendalam (Cangara, 2016: 33).

Komunikasi adalah sesuatu yang urgen dalam umat manusia. Oleh karenanya, kedudukan komunikasi dalam Islam mendapat tekanan yang cukup kuat bagi manusia sebagai anggota masyarakat dan sebagai makhluk Tuhan. Terekam dengan jelas bahwa tindakan komunikasi tidak hanya dilakukan terhadap sesama manusia dan lingkungan hidupnya saja, melainkan juga dengan Tuhannya. Dalam Al-Qur'an terdapat banyak sekali ayat yang menggambarkan tentang proses komunikasi. Salah satu di antaranya adalah dialog yang terjadi pertama kali antara Allah SW, malaikat, dan manusia. Dialog tersebut sekaligus menggambarkan salah satu potensi manusia yang dianugerahkan Allah SWT kepada manusia, seperti yang terdapat pada Al-Qur'an Surah Al-Baqarah ayat 31-33 (Wahyu Ilaihi, 2013: 2).

Berdasarkan dari dua pengertian di atas, yakni "komunikasi dan dakwah", adalah kegiatan komunikasi, di mana da'i mengomunikasikan pesan dakwah kepada mad'u, baik secara perseorangan maupun kelompok. Secara teknis, dakwah adalah komunikasi da'i (komunikator) dan mad'u (komunikan). Semua hukum yang berlaku dalam ilmu komunikasi berlaku juga dalam dakwah, hambatan komunikasi adalah hambatan dakwah, dan bagaimana mengungkapkan apa yang tersembunyi di balik perilaku manusia dakwah sama juga dengan apa yang harus dikerjakan pada manusia komunikan. (Achmad Mubarok 2010: 12).

Untuk itu, jika menelaah pengertian komunikasi dakwah harus dikaji tidak secara atomestik dengan memilah-milah setiap komponen yang terlibat, tetapi harus ditelaah secara holistik, dengan melihat komponen antara yang satu dengan komponen yang lain secara fungsional, di mana terdapat tujuan yang jelas yang akan dicapai. Komponen di sini yang menjadi komunikan adalah kaum milenial.

Masyarakat atau generasi milenial adalah sekarang ini mereka yang berusia di antara 17-36 tahun. yang kini berperan sebagai mahasiswa, early jobber, dan orang tua muda (Iffah Al Walidah, 2017: 30). Kelompok atau generasi milenial merupakan inovator, karena mereka 
mencari, belajar dan bekerja dalam lingkungan inovasi yang sangat mengedepankan tekhnologi untuk melakukan perubahan didalam berbagai aspek kehidupannya (Iffah Al Walidah, 2017: 30). Kaum milenial adalah kaum yang memaknai semuanya dengan kemodernisasian.

Secara etimologis terminologi modern berasal dari bahasa Latin "moderna" yang berarti sekarang, baru, atau saat ini. Atas dasar itu, manusia dikatakan modern sejauh kekinian menjadi pola kesadarannya. Dalam bahasa Indonesia, istilah modern sendiri adalah adjektif (kata sifat), di mana dalam gramatikal Indonesia sebuah adjektif apabila ditambahi dengan "isasi" berarti mempunyai makna proses, jadi modernisasi merupakan sebuah proses modern. Modernisasi juga bisa diartikan sebagai proses pergeseran sikap dan mentalitas sebagai warga masyarakat umtuk dapat hidup sesuai dengan tuntutan masa kini (KBBI Daring, kbbi.kemendikbud.go.id).

Memahami bagaimana seharusnya melakukan komunikasi dan dakwah pada kalangan milenial di era modernisasi tentunya berbicara strategi apa yang tepat dilakukan agar tujuan dakwah tercapai. Keberhasilan gerakan dakwah sangat ditentukan oleh kompetensi seorang da'i, yaitu sejumlah pemahaman, pengetahuan, penghayatan, dan perilaku serta keterampilan yang harus dimiliki oleh para $d a^{\prime} i$, baik kompetensi substantif maupun kompetensi metodologis.

Da’ijuga harus mengetahui cara menyampaikan dakwah tentang Allah, alam semesta, dan kehidupan, serta apa yang dihadirkan dakwah untuk memberikan solusi, terhadap problema yang dihadapi manusia, juga metode-metode yang dihadirkannya untuk menjadikan agar pemikiran dan perilaku manusia tidak salah dan tidak melenceng. Oleh karena itu sebagai dai tentunya harus dibekali dengan pengetahuan akan Islam dan keahlian yang menunjang dalam bidang dakwah, yaitu pemanfaatan teknologi yang tepat guna untuk berdakwah, dalam hal ini teknologi informasi dan komunikasi.

\section{B. Metode Penelitian/Metode Kajian}

Metode yang dilakukan dalam melakukan penelitian ini adalah kualitatif, yakni penelitian yang bermaksud untuk memahami fenomena yang dialami oleh subyek penelitian misalnya perilaku, persepsi, motivasi, tindakan, dan lain-lain, secara holistik, dan dengan cara deskripsi dalam bentuk kata-kata dan bahasa, pada suatu konteks khusus yang alamiah dan dengan memanfaatkan berbagai metode alamiah (Lexy J. Moleong, 2015: 4).

Pendekatan yang dilakukan adalah fenomenologi yaitu prosedur penelitian yang menghasilkan data deskriptif berupa kata-kata tertulis atau lisan dari orang-orang dan perilaku yang diamati, dengan metode menitik beratkan pada penalaran yang berdasarkan realitas sosial secara objektif dan melalui paradigma fenomenologis. Artinya untuk menangkap hakekat obyek-obyek diperlukan tiga macam reduksi guna menyingkirkan semua hal yang mengganggu dalam mencapai obyektivitas yaitu: Reduksi pertama, menyingkirkan segala sesuatu yang subyektif, sikap peneliti harus obyektif, terbuka untuk gejala-gejala yang harus diajak bicara. Reduksi kedua. Menyingkirkan seluruh pengetahuan tentang obyek yang diperoleh dari sumber lain, dan semua teori dan hipotesis yang sudah ada Reduksi ketiga. Menyingkirkan seluruh tradisi pengetahuan. Segala sesuatu yang sudah dikatakan orang lain 
harus, untuk sementara dilupakan, kalau reduksi-reduksi ini berhasil, maka gejala-gejala akan memperlihatkan dirinya sendiri atau dapat menjadi fenomin (Lexy J. Moleong, 2015: 6).

\section{Hasil dan Pembahasan}

Peradaban semakin maju pada zaman modern ini, boleh kita sebut sebagai era teknologi informasi yang canggih. John Naisbitt, mengungkapkan "we are moving toword the capability to communicate anything to anyone, anywhere, anyfrom-voice, data, textor emage at the speed of light (kita sedang bergerak ke arah kemampuan berkomunikasi apa saja kepada siapa pun, di mana pun, berbentuk apa pun (baik itu) suara, data, tulisan atau gambar (citra) dengan (menggunakan kecepatan suara) (Amin Samsul Munir, 2010: 23).

Hal ini juga berpengaruh terhadap dakwah Islamiyah, kita harus mampu berdialog, beradaptasi dengan kebudayaan modern dan secara aktif mengisinya. Hal ini hanya bisa dilakukan bila memahami arus modernisasi secara benar dan tidak tertinggal dengan informasi-informasi aktual dari manca negara.

Futurolog John Naisbitt berpendapat, "The new source oof power is not money in the hands of a few but information in the hands of money" (kekuatan baru dewasa ini bukanlah harta karun di tangan segelintir manusia tapi jaringan informasi di tangan banyak manusia). Ungkapan tersebut merupakan sekelumit gambaran era informasi yang mengglobal dan yang menghadang di hadapan umat Islam di manapun berada di muka bumi ini. (Amin Samsul Munir, 2010: 27). Bahkan dalam Islam, informasi itu jelas tidak terbatas (QS. Al-Kahfi [18]: 109).

Karena itu, perlu dikembangkan sistem dakwah yang menggunakan dan memilih teknologi informasi yang efisien dan tepat tentunya, serta bersih sesuai dengan kodrat umat manusia. Zaman yang sudah berubah ini menuntut para da'i mencarikan solusi dalam memberikan problem solving yang mana masalah yang dihadapi sangat komplek. Para da'i dituntut untuk dapat menerjemahkan pesan Islam sesuai dengan manajemen dakwah modern, efektif dan efisien kepada masyarakat luas, maka Islam akan semakin luas jangkauannya dan mudah dimengerti serta tidak disalahmengertikan oleh non muslim. Maka untuk itu semua diperlukan strategi yang tepat.

Dinamisasi kehidupan modern yang semakin tinggi dan sangat kompetitif telah banyak mempengaruhi umat manusia senantiasa memandang persoalan hidup secara pragmatis, logis, serba instan dan bahkan metematis. Keadaan yang demikian ini di samping membawa manfaat berupa kemajuan ilmu pengetahuan dan teknologi yang semakin memudahkan aktifitas manusia, juga telah membawa implikasi negatif berupa lemahnya semangat transendental dan memudarnya hubungan sosial. Implikasi tersebut berlangsung demikian lama, sehingga dewasa ini telah melahirkan berbagai kenyataan sosial yang cukup bertentangan dengan cita-cita (Encep Dulwahab, 2010: 54).

Media merupakan perkembangan dari ilmu dan teknologi sebagai bentuk penguasaan manusia terhadap pemberdayaan akal. Media sangat penting dan memiliki urgensi bagi dakwah terutama media massa yang dapat menjangkau khalayak dengan cepat. Belum pernah dalam sejarah, manusia dapat menyebarkan gagasannya dan dapat menyampaikan isi dakwah 
kepada banyak orang dengan cepat. Semua media dapat menjadi media dakwah. Sebaliknya dakwah memberi kontribusi kepada media, dalam bentuk moral dan etika yang dikenal dengan kode etik. Tanpa moral dan etika yang kuat, media terutama media massa tidak dapat melaksanakan semacam "malpraktik". Justru itu kaitan media dengan dakwah dapat berlangsung secara simbiosis mutualis (Wina Sanjaya, 2012: 69). Hubungan ini kemudian dijadikan sandaran dalam melangsungkan kegiatan keduanya secara sekaligus.

Dalam kontek umat Islam di Indonesia di era modernisasi, di mana masyarakatnya sudah sedemikian kritis, maka yang diperlukan adalah dakwah yang berorientasi transformasi sosio kultural dan multimedia dengan suatu pendekatan partisipatif. Intinya adalah bagaimana mewujudkan tujuan dakwah Islam, yang tak lain ialah pengembangan potensi fitrah dan fungsi khilafah kemanusiaan dalam rangka membentuk nizhaamul hayaat (sistem kehidupan sosial) yang diridhai Allah. Tujuan tersebut tak mustahil tercapai karena seperti diungkapkan oleh Nurchalis Majid mengutip analisis Marshall G.S. Hodgson, kemenangan Islam di Jawa khususnya, dan di Indonesia umumnya, begitu sempurna dengan adanya banyak kompromi antara ajaran-ajaran Islam dan unsur- unsur budaya local (M. Ja'far Puteh, 2010: 128).

Untuk itu, strategi dakwah masa depan perlu merumuskan dalam beberapa hal antara lain:

1. Mendasarkan proses dakwah pada pemihakan terhadap kepentingan masyarakat. Itu berarti penolakan terhadap segala bentuk dakwah demi kepentingan lain.

2. Mengintensifkan dialog dan ketertiban masyarakat, guna membangun kesadaran kritis untuk memperbaiki keadaan.

3. Memfasilitasi masyarakat agar mampu memecahkan masalahnya sendiri serta melakukan transformasi sosial yang mereka kehendaki. Jadi bukan sekedar menguraikan masalah masyarakat supaya dipecahkan pihak lain,

4. Menjadikan dakwah sebagai media pendidikan dan pengembangan potensi masyarakat, sehingga dengan demikian masyarakat akan terbebas dari kejahilan dan kedhaifan (M. Ja'far Puteh, 2010: 129).

Banyak orang mengakui bahwa hidup menjadi bermakna dan bergairah dengan beragama, karena agama selalu memprediksi kehidupan manusia, jauh ke depan sampai dunia sesudah kematian. Hal tersebut jelas menentramkan manusia dalam menghadapi ketidaktahuan tentang kehidupan sesudah mati. Agama diharapkan dapat menjadi motivasi dan dinamisator kehidupan manusia, menjadikan manusia yang dinamis, ulet, tekun, kerja keras. Manusia yang serasi dan seimbang; berilmu dan beriman, zikir dan pikir, berdoa dan bekerja, beramal dan tawakkal, mujur dan syukur. Dakwah adalah suatu kegiatan yang dapat dilihat secara praktis dan teoritis. Artinya dakwah itu dapat dikembangkan dari segi ilmu dan prakteknya di lapangan. Keduanya merupakan suatu kesatuan dan saling mengisi, sehingga makin baik dari segi ilmu akan makin baik praktek dakwahnya; pengalaman praktek dakwah merupakan realitas nyata yang dapat dipakai memperbaharui wawasan keilmuan dakwah (M. Ja'far Puteh, 2010: 172).

Di era modernisasi ini kita harus menemukan hikmah dan pelajaran yang baik yang sesuai dengan objek dan pesan dakwah yang dapat memberikan jalan keluar yang sebagaimana diinginkan Allah dan Rasulullah. Sehingga industrialisasi berakibat melahirkan:

a. Manusia yang inovatif. 
b. Manusia yang cenderung ingin menginterpretasikan kenyataan secara ilmiah.

c. Manusia yang ingin mengembangkan metode keilmuan dengan mengadakan penelitian dan pengembangan.

d. Manusia yang cenderung menolak kemapanan yang dianggap usang.

e. Manusia yang menghargai waktu, kerja keras, efisiensi, individual, berproduksi, objektif atau secara sinis manusia kikir atau banyak perhitungan dalam shadaqah/ infaq.

f. Gejala-gejala lain yang bisa saja muncul karena watak inovatif dan cenderung adanya perubahan (H. M. Mastury, 2010: 12)

Dengan berbagai poin inovatif yang telah dipaparkan di atas sehingga umat Islam secara general dapat menemukan artikehidupan yang sebenarnya.

Untuk mendukung adanya perubahan dalam berdakwah, para da'i perlu terus menerus meningkatkan wawasan, ilmu dan kemampuan teknis yang diperlukan dalam melakukan dakwah. Da’i tidak boleh merasa puas dengan ilmu yang dimilikinya, melainkan terus belajar, belajar sepanjang hayat (long life education). Apalagi pada era informasi seperti sekarang ini, kemampuan da'i dalam mengoperasikan komputer dan internet merupakan prasyarat yang tidak bisa ditawar-tawar.

Kemudian pada era modern ini, ilmu yang berkembang bersifat multidisipliner dan komplementer. Ilmu agama yang selama ini menjadi pegangan da’i (sumber utama) perlu diperkuat dengan keilmuan lainnya agar apa yang disampaikan ke masyarakat menjadi kokoh dan dapat dioperasionalkan di lapangan. Ilmu agama Islam dapat diperkuat dengan menggunakan kajian ilmu psikologi, sosiologi, sejarah dan sebagainya. Oleh karena itu, dä perlu memperkuat ilmu agama yang dimilikinya dengan menambah wawasan dan pengetahuan yang berdasar dari ilmu-ilmu sosial, humaniora maupun ilmu-ilmu alam (Abdul Basit, 2013: 87).

Contoh menarik fatwa Syekh Adil al-Kalbani, salah seorang Imam Mesjid Mekah, yang melawan arus pendapat umum di kalangan ulama Saudi. Al-Kalbani, yang semula membela pendapat yang mengharamkan musik dan nyanyian tiba-tiba berubah pikiran dan menganggap bermain musik dan menyanyi tidaklah bertentangan dengan ajaran Islam. Fatwa ini mendapat kritik keras dari kalangan ulama senior Saudi Arabia yang menganggap bermusik dan bernyanyi, baik dilakukan di antara orang banyak maupun sendirian, diharamkan oleh syariat Islam. Wacana tentang musik dan nyanyian ini cukup mendapat perhatian dan dibicarakan dalam media massa. Banyak ulama yang yang menentang akan tetapi tidak sedikit yang mendukung al- Kalbani (Djohan Effendi, 2010:6). Jika fatwa tersebut hanya berpedoman pada sumber agama saja tanpa memperhatikan kajian sosiologi masyarakat, maka fatwa tersebut akan bertabrakan dengan realitas yang berkembangan di masyarakat bahwa musik merupakan kebutuhan masyarakat dan bahkan menjadi industri kreatif yang bisa mensejahterakan masyarakat.

Strategi dan metode dalam melaksanakan dakwah yang merupakan sebagai suatu sistem untuk dapat menarik para pendengar agar dapat terserab berbagai pesan dan materi yang akan disampaikan dengan menggunakan berbagai metode dan sistem agar materi 
tersebut dapat dicerna dengan baik dan maksimal, terdapat dua sistem yang sangat efektif di antaranya adalah:

Pertama, Strategi merupakan suatu rencana tindakan termasuk penggunaan metode dan pemanfaatan berbagai sumber daya atau kekuatan. Dengan demikian, strategi kan proses penyusunan rencana kerja, belum sampai pada tindakan. Kedua, Strategi disusun untuk mencapai tujuan tertentu. Artinya dari semua keputusan penyusunan strategi adalah pencapaian tujuan. Oleh sebab itu, sebelum menentukan strategi, perlu dirumuskan tujuan yang jelas serta dapat diukur keberhasilan (Moh. Ali Aziz, 2012: 350).

Strategi atau metode dakwah sendiri di masa modern ini haruslah dilihat dari banyak sisi. Mad'u atau mitra dakwah di masa modern ini adalah generasi milenial. Generasi milenial (sebutan generasi berdasarkan demografi dan disebut juga generasi $\mathrm{Y}$ ) menjadi perbincangan hangat karena terlahir pada saat revolusi teknologi informasi dan komunikasi serta jumlah populasinya yang cukup besar, yaitu sekira 34 persen dari penduduk Indonesia. Umumnya, generasi milenial lahir dalam rentang tahun 1981 sampai 1994. Dengan demikian generasi ini adalah mereka yang berumur 15 hingga 35 tahun. Generasi ini sudah mengenal teknologi seperti komputer, video games, dan smartphone. Beberapa studi tentang generasi milenial menggambarkan mereka yang terkategori milenial dalam berkomunikasi banyak menggunakan teknologi komunikasi instan seperti email, SMS, instant messaging dan media sosial seperti Facebook, Line, Path, Instagram, Whatsapp dan Twitter. Mereka juga suka bermain game online. Generasi ini dikenal sangat senang menghabiskan hidupnya di jejaring media daring. Generasi ini melihat dunia tidak secara langsung melainkan hidup di dunia maya. Mulai dari berkomunikasi, berbelanja online, mendapatkan informasi, dan kegiatan lainnya (islamdakwah.com, 2020). Maka dari itu, generasi milenial sangat akrab dengan media daring dengan media sosialnya.

Pemanfaatan media sosial sebagai wasilah dakwah adalah strategi jitu dalam berdakwah di kalangan milenial ini di era modernisasi seperti sekarang. Media sosial memiliki ciri-ciri antara lain: pesan yang disampaikan tidak hanya untuk satu orang saja, namun bisa untuk banyak orang; pesan yang disampaikan bebas, tanpa harus melalui gate keeper, pesan yang disampaikan cenderung lebih cepat dibanding media lainnya; dan penerima pesan yang menentukan waktu interaksi. Perkembangan media sosial kini semakin pesat. Hampir setiap orang memiliki akun media sosial. Hal ini karena dapat diakses kapanpun dan dimanapun tanpa harus mengeluarkan banyak biaya. Cukup menggunakan mobilephone/handphone yang dikoneksikan pada jaringan internet. Jika untuk memiliki media tradisional seperti televisi, radio, atau koran dibutuhkan modal yang besar dan tenaga kerja yang banyak, maka lain halnya dengan media sosial. Seorang pengguna media sosial bisa mengakses menggunakan media sosial dengan jaringan internet bahkan yang aksesnya lambat sekalipun, tanpa biaya besar, tanpa alat mahal dan dilakukan sendiri tanpa bantuan yang lain. Pengguna media sosial dengan bebas bisa mengedit, menambahkan, memodifikasi baik tulisan, gambar, video, grafis, dan berbagai model content lainnya.

Berbicara mengenai media sosial tidak terlepas dari kelebihannya dalam fasilitasi membagi ide, bekerja sama, dan membangun komunitas. Selain kecepatan informasi yang bisa diakses dalam hitungan detik, menjadi diri sendiri dalam media sosial adalah alasan 
mengapa media sosial berkembang pesat. Tidak terkecuali, keinginan untuk aktualisasi diri dan kebutuhan menciptakan personal branding.

Media sosial adalah sarana yang dibuat untuk memudahkan interaksi sosial dan komunikasi dua arah. Dengan semua kemudahan yang diberikan oleh media sosial ini, penyebaran informasi dari satu individu ke individu lain menjadi sangat mudah (Cindy Rizal Putri Paramitha, 2011: 17).

Dengan demikian, media sosial adalah media online yang penggunanya dapat saling berpartisipasi melalui blog, jejaring sosial, forum dan dunia virtual. Blog dan jejaring sosial merupakan bentuk media sosial yang paling umum digunakan oleh masyarakat di seluruh dunia. Media sosial digunakan untuk bersosialisasi satu sama lain dan dilakukan secara online yang memungkin- kan manusia saling berinteraksi tanpa dibatasi ruang dan waktu.

Media sosial terbagi dalam beberapa jenis, yaitu: social networks (jejaring sosial), media sosial untuk bersosialisasi dan berinteraksi seperti Facebook; discuss media, media sosial yang memfasilitasi obrolan; share, media sosial yang memfasilitasi untuk saling berbagi file, video, music, dan lain-lain.; publish, seperti Blog; social game; MMO; virtual world; livecast; livestream; dan micro blog. Media sosial memungkinkan seseorang berkomunikasi satu sama lain di manapun dan kapanpun, tidak peduli seberapa jauh jarak mereka, dan tidak peduli siang atau pun malam. Saat ini media sosial memiliki dampak besar pada kehidupan di zaman modern. Seseorang yang asalnya "kecil" bisa seketika menjadi besar dengan media sosial, begitupun sebaliknya orang "besar" dalam sedetik bisa menjadi "kecil" dengan media sosial.

Gagasan McLuhan yang mengatakan bahwa "The medium is the message", merupakan terbukanya pintu dalam perkembangan teknologi termasuk di dalamnya adalah media sosial. Media sosial menjadi bagian dari perkembangan itu. Media dipandang sebagai perluasan dari alat indra manusia, telepon merupakan perpanjangan telinga dan televisi adalah perpanjangan mata. Maka, dengan menggunakan media sosial manusia seperti saling berkomunikasi secara langsung (Muhammad Habibi, 2018: 116).

Perkembangan media sosial saat ini tidak luput dari kecanggihan mobilephone. Bahkan, mobilephone berupa smartphone menjadi kebutuhan pokok dalam berinteraksi satu sama lainnya, baik untuk urusan pekerjaan, berdiskusi, dan sebagainya. Untuk mengakses media sosial pun murah dibandingkan dengan media elektronik, cetak, dan sejenisnya. Pengguna media sosial dapat mengaksesnya meski dengan jaringan internet yang koneksinya lambat.

Inilah tantangan sekaligus peluang dakwah yang harus dieksekusi. Untuk itu, ada dua hal yang dapat dilakukan. Pertama, terkait dengan penggunaan media dakwah. Pada era digital saat ini, gadget dan media sosial tidak lepas dari generasi milenial. Maka, gadget dan media sosial harus dijadikan wasilah dakwah. Pesan dakwah harus dikemas melalui konten-konten yang akrab dengan generasi kekinian. Penggunaan portal dakwah dengan konten tidak selalu berupa tulisan, namun juga dapat dikemas dalam bentuk vlog, soundcloud, infografis, dan juga meme, dimuat di YouTube agar dakwah makin meluas. Dakwah juga dapat dilakukan secara online dengan memanfaatkan YouTube, Instagram, dan sebagainya, sebelum akhirnya bisa fenomenal secara offline. Kedua, pengemasan pesan-pesan dakwah harus menarik. Sebab, sebaik apapun materi dakwah tanpa didukung dengan kemasan yang menarik terkadang 
ditinggalkan orang (Muhammad Habibi, 2019: 116). Dengan dua pendekatan tersebut tantangan dakwah pada generasi milenal dapat dilalui dan diselesaikan dengan baik.

Penggunaan media sosial yang beragam dan platform yang baru seperti Tik Tok, Snack Video, dan lainnya jelas sangat membantu pada da’i dalam menyampaikan pesan dakwah dengan bahasa agama yang mudah dipahami dan dikemas dengan bahasa dan tema kekinian. Inilah peluang penggunaan media dakwah yang dapat menyasar ke para kaum milenial yang memang dalam kehidupan sehari-hari tidak bisa lepas dari teknologi informasi. Maka kembali dituntut kepiawaian da'i dalam pemanfaatan media ini, tentunya da' $i$ harus lebih banyak belajar dalam penggunaan media sosial dan platformnya.

Media sosial yang mempergunakan jaringan internet jelas memiliki keunggulan. Kelebihan internet dibanding media lainnya untuk memudahkan proses dakwah, yaitu: pertama, tidak terhalang oleh ruang dan waktu. Dakwah melalui internet dapat diakses di mana saja, oleh siapa saja, dan kapan saja. Kedua, dakwah menjadi lebih variatif. Dakwah tidak lagi disampaikan dengan cara konvensional, Kehadiran cyber memberikan banyak cara untuk menyampaikan pesan-pesan dakwah. Selain tulisan, materi dakwah bisa dalam bentuk gambar, audio, e-book (buku elektronik) ataupun video, sehingga objek dakwah dapat memilih bentuk media yang disukai. Ketiga, jumlah pengguna internet semakin meningkat. Pertumbuhan pengguna internet yang selalu meningkat merupakan kabar baik bagi para da'i yang akan berdakwah di dunia maya, karena objek dakwah pun semakin meningkat. Keempat, hemat biaya dan energi. Dengan menyajikan materi dakwah di internet, objek dakwah tidak perlu datang ke narasumber dan membeli buku untuk menjawab masalah yang dihadapi. Sehingga bisa membantu saudara kita agar tidak mengeluarkan biaya dan tenaga ekstra guna memperoleh informasi yang mereka cari (Pardianto, 2013: 7).

Media sosial menawarkan multimedia berupa gambar, video, maupun desain yang disebarluaskan ke pengguna lainnya dan salah satu contohnya adalah YouTube. YouTube adalah penyedia layanan video terbesar saat ini dan merupakan media untuk upload secara gratis. Para pengguna dapat memuat, menonton, dan berbagi klip video secara gratis. YouTube juga sangat cocok bagi yang ingin mencari informasi tanpa harus membaca artikel. Pada umumnya video-video di YouTube adalah video klip, acara TV, film serta video buatan para penggunanya sendiri.

Manfaat lain dari penggunaan YouTube adalah bahwa isinya dapat disiarkan kepada jutaan pemirsa. YouTube tersedia di hampir setiap negara di dunia dan di setiap komputer yang memiliki akses internet, serta dikunjungi setiap hari oleh jutaan orang. YouTube merupakan tempat filesharing bagi semua membernya di mana kita bisa mencari atau upload video rekaman kita untuk dapat disaksikan oleh orang lain. Dalam konteks dakwah, kebutuhan publik akan video durasi pendek dalam rangka menjawab kebutuhannya sangat tinggi. Beberapa fakta menunjukkan banyaknya media mania yang menonton YouTube.

Konten atau pesan dakwah harus diviralkan. Viral jika dikaitkan dengan komunikasi dapat bermakna proses komunikasi yang secara berantai memperbanyak diri. Konsep kerjanya seperti berkembangbiaknya virus, yaitu memperbanyak (mereplikasi) dirinya. Strategi viral dahulu terjadi dari orang perorang, tersebar dari mulut ke mulut. Kini, dengan perkembangan media yang sangat canggih, viral terjadi di ruang-ruang media sosial dalam pergaulan di dunia maya, misalnya dengan berkicau di Twiter, menyebarkan tautan berita, 
video, dan sebagainya. Viral di media semacam ini sangat memungkinkan konten dakwah dapat menyebar dengan cepat. Menyebarkan konten dakwah melalui media tidak cukup dengan melakukan viral saja. Namun, juga harus mengetahui traffic yang ramai dan pas untuk menyebarkannya. Tanpa mengetahui dan menyesuaikan dengan waktu kebanyakan orang mengakses sebuah media, maka pesan tidak sampai kepada banyak orang (Muhammad Habibi, 2018: 114).

Dalam menyampaikan pesan dakwah sendiri harus memperhatikan tiga komponen, yaitu makna, simbol yang digunakan untuk menyampaikan makna, dan bentuk atau organisasi pesan. Simbol terpenting adalah kata-kata (bahasa), yang dapat mempresentasikan obyek (benda), gagasan, dan perasaan, baik ucapan (percakapan, wawancara, diskusi, ceramah, dan sebagainya). Pesan juga dapat dirumuskan secara nonverbal, seperti melalui tindakan atau isyarat anggota tubuh (acungan jempol, anggukan kepala, senyuman, tatap muka, dan sebagainya), juga melalui musik, lukisan, tarian, film, dan sebagainya. Menyampaian pesan dapat pula melalui lisan, tatap muka, langsung atau menggunakan media/saluran (Widjaja, 2000: 14).

Selain komponen, pesan juga memiliki sifat khusus, yaitu bersifat informatif, persuasif, dan koersif. Pesan bersifat informatif karena hanya memberikan informasi. Dalam situasi tertentu, pesaninformatif lebih berhasil dari pada pesan persuasif. Pesan persuasif berisi bujukan yang membangkitkan pengertian dan kesadaran seseorang. Sedangkan pesan koersif bersifat memaksa. Bentuk yang terkenal dari penyampaian pesan koersif adalah agitasi, yakni dengan penekanan-penekanan yang menimbulkan penekanan batin dan ketakutan di antara sesama kalangan publik. Pesan koersif dapat berbentuk perintah, intruksi dan sebagainya (Deddy Mulyana, 2005: 20).

Beberapa konsep pesan di atas dapat menjadi acuan dalam mengemas pesan dakwah. Jika dikombinasikan, maka mengemasnya dapat dilakukan dengan berbagai cara, antara lain sebagaimana yang dikemukakan Wilson yaitu dengan memerhatikan dimensi-dimensi abstraksi pesan, kesesuaian pendengar, jenis-jenis perancangan strategi pesan untuk mencapai tujuan tertentu atau untuk mengoordinasikan berbagai macam tujuan, jenis-jenis tema isi pesan, pemilihan kata-kata yang khusus, dan lain-lain. agar pesan dapat diterima dengan baik oleh komunikan (penerima pesan), maka pesan komunikasi yang terdiri dari isi pesan dan lambang harus diproduksi dengan sangat hati-hati.

\section{Simpulan}

Komunikasi dakwah kini tidak lagi cukup dengan cara-cara konvensional. Perkembangan zaman dan era yang sudah modern, teknologi yang kian cepat menuntut penyesuaian. Dakwah harus lebih optimal disampaikan lewat media sosial, karena generasi milenial lebih cenderung menggunakan media-media serta aplikasi-aplikasi yang sifatnya interaktif, seperti Whatsaap, YouTube, Facebook, dan lainnya. Karena itu, da’i disarankan untuk memanfaatkan media sosial semaksimal mungkin dalam rangka menjangkau mad'u yang lebih luas sehingga pesan dakwah terserap lebih banyak. 
Strategi dan metode tepat guna tentu diperlukan dalam melaksanakan dakwah yang merupakan sebagai suatu sistem untuk dapat menarik para penikmat dakwah agar dapat terserap berbagai pesan dan materi yang akan disampaikan dengan menggunakan berbagai metode dan sistem agar materi tersebut dapat dicerna dengan baik dan maksimal. Maka dari itu penggunaan bahasa, memahami karakter media social yang dipergunakan, juga konten apa yang sesuai sebagai bentuk penyampaian pesan dalam komunikasi juga perlu diperhatikan, dengan demikian tujuan dakwah di kalangan milenial di era modernisasi ini dapat dicapai.

\section{Daftar Pustaka}

Al Walidah, Iffah. (2017), Tabayyun Di Era Globalisasi Millenial dalam Jurnal Living Hadis Vol. 2 nomor 1, 2017.

Aida Noer Aini, Muhamad Ridwan Effendi, E. N. (2021). Strategi Menanamkan Nilai Nilai Akhlak Melalui Integrasi Pendidikan. Paedagogie, 2(34-47). https://doi.org/doi.org/10.20211/pdg.02.1.04

Aziz, Moh. Ali. (2012), Imu Dakwah. Jakarta: Kencana.

Basit, Abdul. (2013), Jurnal Komunikasi Islam | ISBN 2088-6314 | Volume 03, Nomor 01, Juni 2013 Jurusan Komunikasi dan Penyiaran Islam, Fakultas Dakwah IAIN Sunan Ampel - Asosiasi Profesi Dakwah Islam Indonesia.

Dulwahab. Encep. (2010), Dakwah di Era Konvergensi Media. Jurnal Ilmu Dakwah Vol. 5 No. 16 Juli- Desember 2010.

Effendi, Djohan. (2010), Islam di Antara Teks dan konteks, makalah disampaikan dalam Annual Conference on Islamic Studies (ACIS) ke-10, Banjarmasin, 1-3 Nopember. 2010.

Effendi, M. R. (2021). Relasi Agama dan Masyarakat; Studi Tentang Interaksi Masyarakat Bandung Barat dan Jamaah Tabligh. Hayula, 5(1), 1-24.

https://doi.org/https://doi.org/10.21009/hayula.005.1

Effendi, M. R., Kahmad, D., Solihin, M., \& Wibisono, M. Y. (2021). Relasi Agama dan Masyarakat: Studi Tentang Interaksi Masyarakat Bandung Barat dan Jamaah Tabligh. Hayula: Indonesian Journal of Multidisciplinary Islamic Studies, 5(1), 1-24.

Habibi, Muhammad, (2019) Optimalisasi Dakwah Melalui Media Sosial di Era Milenial, Jurnal Komunikasi Islam dan Kehumasan (JKPI), Vol. 3, No 1, 2019 ISSN: 2621-9492.

Hafied, Cangara, H. (2018) Pengantar Ilmu Komunikasi. Edisi Ketiga. Cetakan 18. Depok: Rajawali Pers.

Ilaihi, Wahyu. (2013), Komunikasi Dakwah, (Bandung: PT Remaja Rosdakarya)

Mahadi, Ujang. (2015), Komunikasi dan Dakwah Kontemporer, Bogor: IPB Press.

Mastury, H. M. (2010). Makalah: Idealisme Dakwah Islamiah Era Industrialisasi. Yogyakarta Moleong, Lexy J. (2015), Metodologi Penelitian Kualitatif, Bandung: PT. Remaja Rosda Karya.

Mubarok, Achmad. (2012), Psikologi Dakwah, Jakarta: Pustaka Firdaus.

Muhtadi, Asep Saeful. (2015), Komunikasi Dakwah, Bandung: Simbiosa Rekatama Media. Mulyana, Deddy. (2017), Ilmu Komunikasi Suatu Pengantar, Bandung: Remaja Rosdakarya Munir, Amin Samsul. (2010), Rekonstruksi Pemikiran Dakwah Islam, Jakarta: Sinar Grafika Offset. 
Paramitha, Cindy Rizal Putri. (2010), Analisis Faktor Pengaruh Promosi Berbasis Sosial Media Terhadap Keputusan Pembelian Pelanggal dalam Bidang Kuliner, Tesis, Fak. Ekonomi UNDIP, Semarang,

Puteh, M. Ja'far. (2010), Dakwah di Era Globalisasi: Strategi Menghadapi Perubahan Sosial. Jakarta: Kencana

Pardianto. (2013), Meneguhkan Dakwah Melalui New Media, Jurnal Komunikasi Islam, ISSN 2088-6314, Volume 03, Nomor 01, Juni 2013.

Sanjaya, Wina. (2012), Media Komunikasi Pembelajaran, Jakarta: Kencana. Shihab, M. Quraish. (2012), Membumikan Al-Qur'an, Bandung: Mizan.

Widjaja. (2010), Ilmu Komunikasi Pengantar, Jakarta: Studi, Rineka Cipta. (https://islamdakwah.com/pentingnya-dakwah-islam-zaman-now.html. (KBBI Daring, kbbi.kemendikbud.go.id) 